\title{
Public Spending and Economic Growth in the Rentier State: The Case of Kuwait
}

\author{
Ebrahim Merza ${ }^{1} \&$ Noorah Alhasan ${ }^{1}$ \\ ${ }^{1}$ Economics Department, Kuwait University, Kuwait \\ Correspondence: Ebrahim Merza, Economics Department, Kuwait University, Kuwait. E-mail: \\ emerza2@hotmail.com
}

Received: April 12, 2016 Accepted: April 21, 2016 Online Published: July 7, 2016

doi:10.5539/ass.v12n8p160 URL: http://dx.doi.org/10.5539/ass.v12n8p160

\begin{abstract}
This paper examines the validity of Wagner's hypothesis in Kuwait looking specifically at government expenditures in health, education and infrastructure. Using time series analysis, the paper has found a long-run equilibrium relationship between GDP growth and the specified government expenditures. It, however, only found one causal relationship between development expenditures and GDP growth. As such, the paper proposes an expansion in government spending on development projects and reevaluates budget allocation in health and education.
\end{abstract}

Keywords: public spending, economic growth, Rentier state, Kuwait

\section{Introduction}

Governments play an essential role in the process of economic development; the way they allocate their resources and govern their institutions has an effect on the economy that would even extend to future generations. This leads to the realization that governments should manage their budget with extreme scrutiny in order to insure that future generations will not be harmed by mismanagement.

In 1893, German economist Adolph Wagner proposed that a positive relationship exists between economic development and the size of government spending. This proposition has gained so much research it has later been seen as a hypothesis and even more so as a law. Many empirical time series research has been conducted testing the hypothesis and in general it has gained strong support with very few exceptions. However, the past two decades have seen research that revisits Wagner's hypothesis with empirical results that do not support the 'law.'

\subsection{Purpose of the Study}

The purpose of this paper is to present the theoretical argument of Wagner's hypothesis, review the existing literature on the hypothesis and growth models, and examine Wagner's hypothesis to the Kuwaiti economy looking specifically at which socioeconomic aspect of government spending has most effect on economic growth. The aspects examined in this paper will be public spending on education, health and infrastructure.

\subsection{Paper Structure}

The structure of the paper will be divided into several integral parts. Section 2 of the paper will handle the literature review, which includes classical endogenous growth model, the anatomy of a rentier state and previous related research on Wagner's hypothesis. Section 3 will handle data and methodology, which includes the nature of data, model design and empirical procedure. Section 4 will present the results and its statistical analysis while section 5 will handle the discussions and policy. Finally, section 6 will conclude the presented paper.

\section{Literature Review and Theoretical Perspective}

A primary objective of every country is to increase the speed of economic growth and economic development by improving the competitiveness of national firms in the global markets (Riasi, 2015; Riasi \& Pourmiri, 2015).

Economic growth has been a subject that many economists from different schools have discussed over time. It is a subject that concerns every nation since they all strive to increase the people's standard of living by reallocating resources as efficiently as possible. This section will look at growth models, the rentier state, and Wagner's hypothesis. 


\subsection{Endogenous Growth Model}

The neoclassical theory of economic growth proposes that real GDP growth is divided into two categories. The first being growth of factor inputs, i.e. labor and capital. The second category is the growth of output relative to growth of inputs, i.e. economies of scale. This theory mostly concentrates on the effect of capital, that's being realized through labor, on economic growth. At first, it implies that national savings, facilitated through capital, increases economic growth. However, after Solow's economic growth model, it has been shown that an increase in national savings does not permanently increase the growth rate, and that other factors play a more effective role in economic growth (Gordon, 2014).

Nonetheless, capital is still a major player in economic development. Specifically, infrastructure, technological advances and human capital, are the most important components of capital that affect economic growth.

Extensive research has been done to test the effects of public spending on economic growth. Starting with the augmented Solow growth model, it incorporates human capital accumulation in addition to physical capital formation as a determinant to the steady-state level of income per capita (Mankiw, Romer, \& Weil, 1992). It further states that differences in education and population growth would explain differences in income per capita between countries.

According to Barro (1991) however, the growth rate is significantly positively related to the starting level of human capital. He further states that public expenditures on education are considered as investment than a form of consumption and that they are more likely to affect private-sector productivity, which will also matter to private investment.

Linking health expenditures to labor productivity, it has also been shown that improvements in health increase output through the accumulation of human capital (Bloom, Canning, \& Sevilla, 2004). Specifically, public spending on health has a positive and statistically significant effect on economic growth, in which a one-year improvement in a population's life expectancy has a contributed to an increase of four percent in output (Bloom et al., 2004).

As for infrastructure, neoclassical models and growth models have emphasized the importance of capital on economic growth. According to Munnell (1992), public infrastructure spending has a positively significant effect on economic growth as well as providing immediate economic stimulus.

Nonetheless, one does not simply talk about public spending without first distinguishing consumptive from productive expenditures. Productive public spending is designed to exogenously promote production, whereas consumptive public spending is formulated to increase households' utility (Chen, 2006). Therefore, an increase in the consumptive public expenditure lowers economic growth because it has no direct effect on private-sector productivity (Barro, 1990).

According to Chen (2006), East Asian countries have had higher percentage of productive public spending and achieve higher economic growth rates than other countries. Furthermore, a high share of productive public spending may not be the main underlying reason for explaining economic growth differences amongst countries but can be seen as a result of the governments' optimal choices (Chen, 2006).

Nonetheless, public expenditures that normally carry a productive nature can turn into a consumptive one if it reaches an excessive amount (Devarajan, Swaroop, \& Zou, 1996). Productive public expenditures, often thought as the leading force to development, might have reached excessive levels in developing countries, which turned them unproductive at the margin while consumptive expenditures are actually productive at the margin (Devarajan et al., 1996).

\subsection{The Rentier State}

In relation to economic growth, the rentier economy proposes a special case with regards to public spending and specifically for the oil-state economies. According to Beblawi and Luciani (1987), the rentier economy is, "either an economy substantially supported by expenditure from the state, while the state itself is supported from the rent accruing from abroad; or more generally an economy in which rent plays a major role" (p. 11). Given the structure of the oil revenues, the massive levels of oil rents increased the involvement of the government in the economy and enabled it to expand its public sector. This in turn made the government the prime agent of the economy while the role of the private sector shrunk relatively (Abdulla, 1999).

In the rentier state, the government has total control over the revenues received from the exports of the rent-producing sector, in which it then establishes the links between the rent-producing sector and the rest of the economy through the expenditure side of the public budget (Abdulla, 1999). This leads to the conclusion that the 
rest of the economy is involved only in the utilization and distribution of the wealth generated from the rents.

Nonetheless, the government uses oil revenues to meet current expenditures as well as to invest some of these revenues in income-generating projects. In turn, public spending on projects, wages and transfer payments will have a multiplicative effect on the economy that is similar to the Keynesian multiplier (Abdulla, 1999). Stauffer (1987, p. 33) uses the term "rentier multiplier" in order to indicate how the injection of real resources coming from export oil rents largely increases effective demand and as such the increase in income is greater than the injection of the oil revenue. The only difference from the classical Keynesian multiplier is that it is caused by real resource injections rather than budget deficits (Stauffer, 1987). This completely changes the way public budget is managed in a rentier state and as such behaves differently than the classical open economy. Specifically in the rentier economy, the rentier multiplier loses some of its effect due to leakages caused mainly by high reliance on imports and expatriate workers (Abdulla, 1999).

In relation to this paper, the effect of government expenditures on economic growth can be realized through effective spending on the various budget components, i.e. education, health and infrastructure. This paper will specifically look at Kuwait's past government budgets and how different components' expenditures affect the GDP. The parts that will be investigated are of a civil nature. They will be education, health, transportation, communication and energy.

Özyavuz and Schmid (2015) study the relationship between economic growth and oil revenue in the 6 gulf countries. The authors were arguing that whether the GCC members have undertaken reforms and changes for depending less on oil-wealth and for reaching a more diversified economy. Despite their efforts and achievements - both endogenous as exogenous factors - are still inhibiting the development processes in each country.

\subsection{Wagner's Hypothesis}

As stated before, Wagner's hypothesis states that there exists a relationship between economic growth and size of government. Many empirical studies have supported this hypothesis to be promoted to a 'law,' however in the recent decades, changes in economic structures have shown that the law does not hold in some cases and/or certain periods.

Durevall and Henrikson (2011) conducted a historical reassessment of Wagner's hypothesis on data spanning from early 19th century until present day (1800-2006) in Sweden and the UK. Their main results were that Wagner's hypothesis does not hold in the long runfor Sweden, a welfare state, and the UK. However, the hypothesis holds for certain time periods, specifically when the economy goes through the process of modernization, like 40-50 years before WWII and 30-40 years after WWII.

In developing, oil-exporting Nigeria, Babatunde (2011) tested the validity of Wagner's hypothesis using annual data of government expenditure and real GDP from 1970-2006. The author's main results were that there exists no long-run relationship between government expenditure and output, thus refuting Wagner's hypothesis for the case of modern Nigeria.

Whereas in Turkey, Tasseven (2011) has also tested for the validity of Wagner's hypothesis using annual data of public expenditures and real GDP, spanning approximately the same time period as Nigeria (1960-2006) and the author's result show that there exists a long-run relationship between government expenditure and output. This can possibly go back to Durevall and Henrikson (2011) observation in which Wagner's hypothesis would only hold during the economy's period of modernization, where it is evident that Turkey has gone through a substantial degree of modernization relative to Nigeria. However, in Pakistan the support for the Wagner's Hypothesis was found to be weak (Muhammad et al., 2015).

Specifically in Kuwait, Burney (2002) examined Wagner's hypothesis using Kuwait as a model where he conducted empirical analysis on the relationship between public expenditures and national income as well as several socioeconomic variables from 1969 to 1994. The results that he found show that there is little evidence to support the validity of Wagner's hypothesis. However, a long-run equilibrium relationship between national income and public expenditures only existed when he incorporated economy openness in the model, suggesting a restriction to Wagner's hypothesis in the case of Kuwait.

Whereas Al-Faris (2002) also conducted research on the validity of Wagner's hypothesis, testing the relationship between public expenditures, both current and capital expenditures, and economic growth, where he used the Gulf Cooperation Council (GCC) countries as a model from 1970-1997. However, his results show that there exists a long-run relationship between national income and public spending, therefore lending strong support to the validity of Wagner's hypothesis. 


\section{Data and Methodology}

This section will present the empirical data used in this paper to conduct an econometric analysis on the question of whether there exists a long-run equilibrium relationship between government spending on education, health and infrastructure and GDP. Furthermore, this section will discuss the model design used to address the presented question and delves into the methodology used to approach the issue.

\subsection{Data Description}

The data used in this paper are the annual public expenditures and the nominal GDP of Kuwait in which they are all attained from the Quarterly Bulletin of the Central Bank of Kuwait (Central Bank of Kuwait, 2013). The annual data used is from 1979 to 2012 and the measurement is in millions of Kuwaiti Dinars (KD). The data is then converted to its natural logarithms for the econometric analysis.

\subsection{Model Design}

According to Wagner's law, as income increases, public spending increases as well. Therefore we can continue to postulate that,

$$
\mathrm{GDP}=\mathrm{f}(\mathrm{CEE}, \mathrm{CHE}, \mathrm{CIE}, \mathrm{DE})
$$

Where,

GDP $=$ Nominal GDP; CEE $=$ Nominal Current Education Expenditures; CHE $=$ Nominal Current Health Expenditures; $\mathrm{CIE}=$ Nominal Current Infrastructure Expenditures; $\mathrm{DE}=$ Nominal Development Expenditures

The series will then be converted into its natural logarithms in order to observe their changes. Furthermore, the natural logs of these macroeconomic variables will capture the rate of growth of them over time. It will follow in the following format,

$$
\operatorname{Ln} \mathrm{GDP}_{\mathrm{t}}=\beta_{0}+\beta_{1} \operatorname{LnCEE}{ }_{\mathrm{t}}+\beta_{2} \operatorname{LnCHE}_{\mathrm{t}}+\beta_{3} \operatorname{LnCIE}_{\mathrm{t}}+\beta_{4} \operatorname{LnDE}_{\mathrm{t}}+\varepsilon_{\mathrm{t}}
$$

Nominal GDP is used as the dependent variable to measure the effect of the ministries' annual expenditures at current prices.

Nominal Current Education Expenditure (CEE) is the amount spent by the Ministry of Education and the Ministry of Higher Education on public schools and public educational programs as well as scholarships for higher education that is provided for Kuwaiti citizens. Since education increases human capital, Nominal Current Education Expenditure should therefore be positively related to Nominal GDP.

Nominal Current Health Expenditure (CHE) is the amount spent by the Ministry of Health on hospitals, clinics and health services that are provided to the public. Since health services produce positive externalities, Nominal Current Health Expenditures should therefore be positively related to Nominal GDP.

Nominal Current Infrastructure Expenditure (CIE) is the amount spent by the government on roads, buildings, utilities such as water and electricity and communication services such as telephone lines and Internet services provided to the public. These current expenditures on infrastructure are taken from Ministry of Electricity and Water, Ministry of Communications and Ministry of Public Works. Since these services produce positive externalities, Nominal Current Infrastructure Expenditure should therefore be positively related to Nominal GDP.

Nominal Development Expenditures (DE) is the amount spent by the government on development projects. They are classified in terms of development spending at the Ministry of Electricity and Water, Ministry of Public Works and the Ministry of Communications. Since development projects benefit the entire economy, it is therefore assumed that development expenditures are positively related to Nominal GDP.

\subsection{Methodology}

When conducting time series analysis, several procedures need to be implemented on the data in order to strengthen the analysis of the output. This section will first test the series for the presence of a unit and determine their order of integration, then construct a Vector Autoregression (VAR) model in order to determine the optimum lag to run the appropriate cointegration test, where finally it will look at the Granger causality amongst the variable in order to finally assess the relationship.

\subsubsection{Unit Root Test}

At first, data needs to be tested for stationarity since nonstationary data produce unreliable estimates in an ordinary least squares (OLS) regression due to the extreme likelihood of positive autocollinearity. The paper hypothesizes that the data chosen for the model exhibits nonstationarity and would test this hypothesis by conducting several unit root tests. Due to the popularity of unit root tests used on time series data, the paper has 
chosen two tests in order to strengthen the analysis. The first is the Augmented Dickey-Fuller (ADF) test and the second is the Zivot-Andrews (ZA) unit root test.

\subsubsection{Augmented Dickey Fuller Test}

In recent literature, most times series data need to be differenced (d) times in order to become stationary. Therefore, a times series like Ln (GDP), for example, is said to be integrated in the order of (d), which is represented as $\operatorname{Ln}(\mathrm{GDP}) \sim \mathrm{I}(\mathrm{d})$.

The ADF test is the most widely used test in times series empirical studies to test for data stationarity. The formal test is utilized by regressing the following equation:

$$
\Delta(\operatorname{Ln~GDP})_{\mathrm{t}}=\alpha_{0}+\alpha_{1} \mathrm{t}+\alpha_{2}(\operatorname{Ln~GDP})_{\mathrm{t}-1}+\sum_{\mathrm{i}=1}^{\mathrm{n}} \alpha_{\mathrm{i}} \Delta(\operatorname{Ln} \text { GDP })_{\mathrm{t}-\mathrm{i}+1}+\varepsilon_{\mathrm{t}}
$$

where $(\mathrm{Ln} G D P)_{t}$ is the economic variable being tested, and $\varepsilon_{\mathrm{t}}$ is the error term normally distributed, i.e. $\varepsilon_{\mathrm{t}} \sim \mathrm{N}(0,1)$.

$(\operatorname{Ln} \text { GDP })_{t}$ is differenced and regressed against a constant $\left(\alpha_{0}\right)$, a time trend $(t)$, and the first lag of (Ln GDP)t. More lags can be added to the equation in order to insure no serial correlation is present in the error term and is automatically chosen by utilizing the Schwarz Information Criterion (SIC) test to confirm no autocorrelation. The E-views program chooses a maximum lag length of 8, where it chooses the lag length with the smallest SIC value (IHS Global Inc., 2013, p. 482).

The null hypothesis of the test follows that $\mathrm{H}_{0}: \alpha_{2}=0$, which means that a unit root is present, against the alternative $\mathrm{H}_{1}: \alpha_{2} \neq 0$, where the test is based on the t-statistics of the coefficient of (Ln GDP). The value of the t-statistic is then tested against the critical values computed by MacKinnon (1996), where if the calculated value is greater than the critical value, then the null hypothesis of a unit root present is rejected.

Burney (2002) used the ADF method to test the order of integration of public expenditures in Kuwait. The results were all types of government expenditures that were specified in his research were integrated in the first order, i.e. I (1). In addition, Al-Faris (2002) also tested for stationarity using the ADF test on Kuwaiti public expenditures in his paper, and all the variables have failed to reject the null hypothesis of a unit root present in their level. Furthermore, Fasano and Wang (2002), tested for stationarity of public expenditures in Kuwait using the ADF test and they have found that expenditures were integrated in the first order.

Nonetheless, the main debate around unit root tests is whether the nature of shocks affected by the time series are transitory or permanent. The standard ADF test does not take into account any structural breaks affecting the time series, thus increasing the likelihood of a type II error. Perron (1989) debates that ADF tests are more inclined towards the non-rejection of the null hypothesis of a unit root in the occurrence of a structural break, in which he specifically states with regards to US macroeconomic variables, "Most macroeconomic time series are not characterized by the presence of a unit root. Fluctuations are indeed stationary around a deterministic trend function. The only 'shocks', which have had persistent effects, are the 1929 crash and the 1973 oil price shock" (1989, p. 1361).

None of the previously mentioned research has tested for a possibility of a structural break in their time series thus possibly affecting the reliability of the ADF test. In order to decrease the possibility of a type II error, this paper will conduct the ZA unit root test in the following section to determine whether the series is difference stationary, i.e. nonstationary with a drift, or trend stationary with a structural break.

\subsubsection{Zivot-Andrews Unit Root Test}

To account for the possibility of a structural break, the Zivot-Andrews (ZA) unit root test was developed by Zivot and Andrews (1992) and incorporates a structural break in the time series when testing for a possible unit root in the series. Furthermore, it allows the test to determine the breakpoint, i.e. the structural break date 'endogenously' from the data by using a different dummy variable for each possible break date. The selection occurs where the t-statistic from the ADF test of unit root is at a minimum. Therefore, a break date will be chosen where the evidence is least favorable for the unit root null (Glynn, Perera, \& Verma, 2007).

However, the ZA unit root test was criticized for the treatment of the structural break periods, since there is a possibility that the structural break does not have a historical significance and as such a thorough economic analysis could not be carried out using this test. Packey and Nasair (2009) explored the Kuwaiti consumption function in the presence of economic structural breaks where they used the ZA unit root test to test for nonstationarity in the real GDP and consumption. Regarding the results, both real GDP and its natural logarithm have failed to reject the test's null hypothesis of a unit root with a structural break in the constant, the trend and both. Therefore, the paper hypothesizes that the GDP variable will also fail to reject the null hypothesis of a unit 
root with a structural break in both the trend and the constant.

\subsubsection{Cointegration Test}

When a linear combination of two or more nonstationary series, integrated in the same order, exhibit stationarity, then these two or more series are considered cointegrated.

Cointegration is useful because should it exist between the chosen nonstationary time series then it indicates that they're not spurious and that their linear combination exhibits a long-run equilibrium relationship. It is worth noting that cointegration testing is more favorable for nonstationary data than to difference the time series into stationarity. That is because cointegration testing is capable of picking up the long-run relationship among the time series whereas differencing them will lose all that long-run information in the process.

The main tests for cointegration are the Engle-Granger two-step method, where it tests for cointegration between two series, and the Johansen cointegration test, where it allows for cointegration testing for two series and more. Furthermore it has been shown by Gonzalo (1994) that the Johansen approach has more result power than its counter, the Engle-Granger two-step method.

Given that this paper aims to explore any cointegrating relationship between more than two series, it will use the Johansen cointegration test as the method of choice. The Johansen Cointegration Test, developed by Johansen and Juselius (1990), is the most widely used method to estimate the long-run equilibrium relationship of the nonstationary time series. The method adopts a maximum likelihood procedure in order to detect any cointegrating relationships between nonstationary series. The number of cointegrating relationships is determined by two test statistics: The Trace test and the Maximal eigenvalue test. The null hypothesis of the Trace test is that the number of cointegrating relationships is less than or equal to ' $r$ ', whereas the Maximal eigenvalue test's null hypothesis is that there exists ' $r$ ' of cointegrating relationships against the alternative of ' $\mathrm{r}+1$.'

In order to run the Johansen test, a lag length must be determined by first running a Vector Autoregressive (VAR) model on all the nonstationary series at level, in which the optimal lag length is chosen according to the minimized value of various information criteria, such as the Likelihood Ratio (LR), the Final Prediction Error (FPE), the Akaike Information Criterion (AIC), the Schwarz Information Criterion (SIC) and finally the Hannan-Quinn Information Criterion (HQ). So for example, if the optimal lag length of the VAR model chosen by the minimized value of the criterion is 3 , then the lag length chosen for the Johansen method is 2 , since the Johansen test is run on the first difference of the time series.

Both Burney (2002) and Al-Faris (2002) used the Johansen cointegration test to examine the existence of a long-run equilibrium relationship between national income and public expenditure in Kuwait. Al-Faris (2002) found that there exists a long-run equilibrium relationship between national income and public expenditures whereas Burney (2002) only found a long-run equilibrium relationship between the variables when economy openness is taken into account.

Fasano and Wang (2002) also used the Johansen cointegration test to examine whether a long-run equilibrium relationship between government revenue and expenditure in the GCC countries. Their findings have shown that there exists a long-run equilibrium relationship between government revenue and expenditure in the GCC countries.

\subsubsection{Granger Causality}

The most widely used test in economics for identifying causality amongst time series data is the Granger Causality. Developed by Clive Granger $(1969,1986)$, the test is considered an inferential approach, in which it is data based regardless of background economic theory. Furthermore, it was developed for time series analysis, which makes it convenient for the paper's purpose.

The test follows that variable X, for example, Granger causes Y if X and Y's past history combined can help to predict the future value of $\mathrm{Y}$ beyond what could have been done with the past value of $\mathrm{Y}$ only. Mathematically it follows,

$$
\begin{array}{r}
\mathrm{Y}_{\mathrm{t}}=\alpha_{0}+\sum_{\mathrm{i}=1}^{\mathrm{n}} \alpha_{1 \mathrm{i}} \mathrm{Y}_{\mathrm{t}-1}+\sum_{\mathrm{i}=1}^{\mathrm{n}} \alpha_{2 \mathrm{j}} \mathrm{X}_{\mathrm{t}-\mathrm{j}}+\mu_{\mathrm{t}} \\
\mathrm{X}_{\mathrm{t}}=\beta_{0}+\sum_{\mathrm{i}=1}^{\mathrm{n}} \beta_{1 \mathrm{i}} \mathrm{X}_{\mathrm{t}-1}+\sum_{\mathrm{i}=1}^{\mathrm{n}} \beta_{2 \mathrm{j}} \mathrm{Y}_{\mathrm{t}-\mathrm{j}}+v_{\mathrm{t}}
\end{array}
$$

Where $\mu$ and $v$ are serially uncorrelated error terms with zero mean, $\alpha_{0}$ and $\beta_{0}$ are constants and $\alpha_{1 \mathrm{i}}, \alpha_{2 \mathrm{j}}, \beta_{1 \mathrm{i}}$ and $\beta_{2 \mathrm{j}}$ are coefficients. The joint null hypothesis states that, for example, $\alpha_{11}=\alpha_{12}=\alpha_{13}=\ldots=\alpha_{1 \mathrm{n}}=0$ where the reported statistic is the F-statistic. A rejection of the null hypothesis, in the case of the example used, would mean that $\mathrm{Y}$ Granger causes $\mathrm{X}$. 
It is worth noting that the Granger causality test can only be conducted on stationary time series. Therefore, the test would lose information on its long-run effect due to the nonstationarity of the time series at level.

\section{Empirical Results}

This section will present all the results obtained from the econometric procedures proposed in the previous section as well as a brief analysis on the impact of these results on the paper's main question. E-views (version 8) software is the choice of econometric program used for the analysis of the time series data.

\subsection{Unit Root Tests}

Table 1. Unit root test results (with intercept and trend)

\begin{tabular}{cccc}
\hline \multirow{2}{*}{ Variable } & ADF & ADF & $Z^{\mathrm{a}}$ \\
& $\mathrm{I}(0)$ & $\mathrm{I}(1)$ & $\mathrm{I}(0)$ \\
\hline Ln GDP & $-1.73[0]$ & $-5.83^{* * *}[1]$ & $-4.34[0](1990)$ \\
Ln CEE & $-0.57[0]$ & $-6.55^{* * *}[0]$ & $-3.67[1](2000)$ \\
Ln CHE & $-1.90[0]$ & $-7.93^{* * *}[0]$ & $-5.32^{* *}[1](2000)$ \\
Ln CIE & $-0.82[1]$ & $-7.63^{* * *}[0]$ & $-3.85[1](1995)$ \\
Ln DE & $-1.60[0]$ & $-5.42^{* * *}[0]$ & $-3.43[0](1989)$ \\
\hline
\end{tabular}

(1) The results are based on the assumption of a constant and a linear trend present in the regressions.

(2) The lag length of the unit root test is specified in brackets [].

(3) The lag length of the unit root test is based on the Schwarz Information Criterion (SIC) for the appropriate length chosen automatically up to 8 lags.

(4) The null hypothesis states that a unit root is present in the series.

$*, * *$, and *** corresponds to the rejection of the null hypothesis of a unit root present at $10 \%, 5 \%$, and $1 \%$ significance level respectively.

aThe ZA unit root method tests for a unit root with a structural break in both the trend and the intercept. Year in parentheses () correspond to the chosen breakpoint date that has been estimated endogenously.

Testing for unit roots has given a clearer image of the data presented. Using the ADF method, all variables have rejected the null hypothesis of a unit root after the first difference, meaning they are all integrated in the first order, i.e. I (1).

Furthermore, the outcome of the ZA unit root test shows that the all the variables with the exception of (Ln CHE) have failed to reject the null hypothesis of a unit root with a structural break in the intercept and trend. As such, the test failed to determine the series as trend stationary with a possible structural break in the intercept and the trend. As for (Ln CHE), the ZA unit root test outcome rejects the null hypothesis of a unit root with a structural break in the trend intercept at the 5\% significance level. However, the calculated breakpoint date presents no historical significance with regards to Kuwait's health expenditures, and as such, the paper cannot use this test as a basis for further investigation.

\subsection{Optimal Lag Length}

Table 2. Optimal lag length order chosen by criterion

\begin{tabular}{cccccc}
\hline Lag & LR & FPE & AIC & SIC & HQ \\
\hline 0 & & $9.31 \mathrm{e}-7$ & 0.302 & 0.536 & 0.377 \\
1 & 181.894 & $2.59 \mathrm{e}-9$ & -5.610 & $-4.209^{*}$ & -5.162 \\
2 & 43.160 & $1.65 \mathrm{e}-9$ & -6.215 & -3.646 & -5.393 \\
3 & 16.042 & $4.28 \mathrm{e}-9$ & -5.694 & -1.958 & -4.499 \\
4 & $39.311^{*}$ & $8.28 \mathrm{e}-10^{*}$ & $-8.395^{*}$ & -3.491 & $-6.827^{*}$ \\
\hline
\end{tabular}

* indicates the optimal lag order chosen by the criterion

The results show that the LR, FPE, AIC, and HQ values were at minimum with a lag order of 4 , whereas the SIC value was at a minimum with a lag order of 1 . Therefore, given that not all the types of criterion have chosen 
unanimously on the optimal lag order for the Johansen test, the paper will run the test twice: once with a lag order of 3 and another with no lagged order.

\subsection{Johansen Cointegration Test}

Table 3. Johansen Cointegration test results (no lags in first differences, linear deterministic trend)

\begin{tabular}{llll}
\hline \multicolumn{1}{l}{ Trace Test: } & & \\
\hline Null & Alternative & Trace Statistic & $5 \%$ Critical Value \\
$\mathrm{r}=0^{*}$ & $\mathrm{r} \geq 1$ & 81.275 & 69.819 \\
$\mathrm{r} \leq 1$ & $\mathrm{r}=2$ & 36.480 & 47.856 \\
\hline \multicolumn{2}{l}{ Maximum Eigenvalue Test: } & & \\
\hline Null & Alternative & Max-Eigen Statistic & Critical Value \\
$\mathrm{r}=0^{*}$ & $\mathrm{r}=1$ & 44.795 & 33.877 \\
$\mathrm{r}=1$ & $\mathrm{r}=2$ & 17.812 & 27.584 \\
\hline
\end{tabular}

* indicates the rejection of the null hypothesis of ' $r$ ' cointegrating relationships at the $1 \%$ significance level.

Table 4. Johansen Cointegration test results (3 lags in first differences, linear deterministic trend)

\begin{tabular}{llll}
\hline Trace Test: & & & \\
\hline Null & Alternative & Trace Statistic & $5 \%$ Critical Value \\
$\mathrm{r}=0^{*}$ & $\mathrm{r} \geq 1$ & 152.749 & 69.819 \\
$\mathrm{r} \leq 1^{*}$ & $\mathrm{r}=2$ & 87.983 & 47.856 \\
$\mathrm{r} \leq 2^{*}$ & $\mathrm{r}=3$ & 43.980 & 29.797 \\
$\mathrm{r} \leq 3$ & $\mathrm{r}=4$ & 7.750 & 15.495 \\
\hline Maximum Eigenvalue Test: & Alternative & Max-Eigen Statistic & \\
\hline Null & $\mathrm{r}=1$ & 64.766 & Critical Value \\
$\mathrm{r}=0^{*}$ & $\mathrm{r}=2$ & 44.002 & 33.877 \\
$\mathrm{r}=1 *$ & $\mathrm{r}=3$ & 36.230 & 27.584 \\
$\mathrm{r}=2 *$ & $\mathrm{r}=4$ & 7.561 & 21.132 \\
$\mathrm{r}=3$ & $\mathrm{y}$ & 14.265 \\
\hline
\end{tabular}

* indicates the rejection of the null hypothesis of ' $r$ ' cointegrating relationships at the $1 \%$ significance level.

The Johansen test results show that without any lags in the first difference and with a linear deterministic trend, the null hypothesis failed to reject at most one cointegrating relationship using both the Trace test and the Maximum Eigenvalue test. However, running the test again with the same assumptions except for using 3 lags instead none, the null hypothesis failed to reject at most 3 cointegrating relationships using both tests.

This means that as a system, several linear combinations of the time series exhibit long-run equilibrium relationship, which can possibly lend support to Wagner's hypothesis but would require further testing to see the direction of causality.

\subsection{Granger Causality}

The Granger Causality test has failed to reject causality between Ln (GDP) and Ln (CEE), Ln (CHE) and Ln (CIE) bi-directionally in which it shows that changes in Ln (CEE), Ln (CHE) and Ln (CIE) are independent to changes in Ln (GDP) and vice versa.

The test, however, rejected the null hypothesis of no Granger Cause from Ln (DE) to Ln (GDP) at the 1\% significance level but failed to reject the null hypothesis of no Granger Cause from Ln (GDP) to Ln (DE) at the 5\% significance level. This might indicate that changes in Ln (DE) levels can predict the changes in Ln (GDP) levels but not vice versa. 
Table 5. Granger causality results (the null hypothesis and probability of non-rejection)

\begin{tabular}{ccc}
\hline Null Hypothesis $\left(\mathrm{H}_{0}\right)$ & $\begin{array}{c}\text { Probability of } \\
\text { not rejecting } \mathrm{H}_{0}\end{array}$ & The results \\
\hline Ln (CEE) does not Granger Cause Ln (GDP) & $17 \%$ & Do not reject $\mathrm{H}_{0}$ \\
Ln (GDP) does not Granger Cause Ln (CEE) & $86 \%$ & Do not reject $\mathrm{H}_{0}$ \\
Ln (CHE) does not Granger Cause Ln (GDP) & $29 \%$ & Do not reject $\mathrm{H}_{0}$ \\
Ln (GDP) does not Granger Cause Ln (CHE) & $43 \%$ & Do not reject $\mathrm{H}_{0}$ \\
Ln (CIE) does not Granger Cause Ln (GDP) & $27 \%$ & Do not reject $\mathrm{H}_{0}$ \\
Ln (GDP) does not Granger Cause Ln (CIE) & $36 \%$ & Do not reject $\mathrm{H}_{0}$ \\
Ln (DE) does not Granger Cause Ln (GDP) & $0.25 \%$ & Reject $\mathrm{H}_{0}$ \\
Ln (GDP) does not Granger Cause Ln (DE) & $6 \%$ & Do not reject $\mathrm{H}_{0}$ \\
\hline
\end{tabular}

This goes alongside to Al-Faris (2002) findings, where Kuwait rejected the no Granger Cause from Capital Expenditure to Real GDP at the 5\% significance level.

Table 6. Granger causality results (direction of causality)

$\operatorname{Ln}(\mathrm{DE}) \quad \Rightarrow \operatorname{Ln}(\mathrm{GDP})$

\section{Discussions and Policy Implications}

Empirical results from previous section show that time series of the selected variables are nonstationary but exhibit a long-run equilibrium relationship. However, only development expenditures show a causal relationship with GDP, in which the direction of the cause goes from development expenditures to GDP. This means that a change in development expenditures will have a future impact on the GDP level but the reverse does not provide enough evidence to support such claim.

The fact that CEE, CHE and CIE do not Granger cause GDP and vice versa does not mean that a long-run equilibrium relationship does not exist as has the opposite been shown through cointegration testing in the previous section. It may indicate that other exogenous factors may have a bigger impact on the causality than the chosen variables. For example, Burney's (2002) findings indicate that the degree of openness in the economy has an effect on the overall relationship between national income and government expenditure. Furthermore, the existence of a long-run equilibrium relationship amongst these variables shows the importance of government spending on education, health and infrastructure on GDP levels and as such lends support to Wagner's hypothesis.

The results, however, shed light on which aspect of government spending has the most impact on GDP, in which in this case it is the development expenditures that have the most impact on GDP levels. In an open small economy with extremely high oil rents, capital expenditures would have a higher impact on economic growth than expenditure on health and education. This is due to the fact that a low-populated economy where the majority of population is considered as temporary residents, the impact of education and health expenditure on GDP will be minimal and as such will not be picked up in the econometric analysis.

Moreover, a closer look at the structure of education and health expenditures shows how the mismanagement of spending can result in the minimal effect of these expenditures to the growth rate of the GDP. According to the Ministry of Finance in Kuwait, between fiscal years 2005/06 and 2012/13, an average of 16\% of government health expenditures were transferred abroad as health expenses, which can be seen as a leakage to the economy. As for education expenditures, during the same fiscal period an average of $58 \%$ of government spending on education were spent on wages. It is worth noting, that the percent of wages is the base salary and does not take into account miscellaneous expenses that account for the total wage received by the worker. The high spending on wages in public education can be seen as a hindrance to the total development of the economy and can pose a threat to the way the budget is allocated in the future.

As such, it is imperative that the government expands on the spending on development projects since they have the greatest impact on economic growth. Therefore, it is of great importance that the government continues with 
its development plan and expand on the proposed projects.

In addition, the government should look at ways to allocate the education and health budgets more efficiently, since changes in these expenditures do not impact future GDP levels. However, it is worth noting that the population structure can play a role in the way the GDP reacts to government spending. As such, it is recommended that further research should be conducted on how demographics impact the validity of Wagner's hypothesis.

\section{Conclusions}

Given that Kuwait is a small open economy with extremely high oil rents, Wagner's hypothesis still holds with regards to a long-run equilibrium relationship between GDP and government expenditures in health, education and infrastructure. Nonetheless, this paper has taken it a step further and examined which aspects of government expenditures has the greatest impact on economic growth. Through Johansen cointegration testing and Granger causality testing, development expenditures have shown the greatest impact on the growth rate of the GDP.

Health and education expenditures also exhibit a long-run equilibrium relationship with the GDP. However, they do not exhibit a causality relationship amongst each other. This can be attributed to the minimal effect of a low population when compared to high oil rents and the possibility of budget allocation mismanagement.

The paper proposes an increase in spending in development projects, specifically relating to infrastructure, and it proposes to reevaluate education and health budget allocations in a way that will increase sustainability and promote overall efficiency while taking into account demographics.

\section{References}

Abdulla, K. (1999). The State in Oil Rentier Economies: The Case of Bahrain. In A. Abdelkarim (Ed.), Change and Development in the Gulf (pp. 51-78). London: Palgrave Macmillan.

Al-Faris, A. (2002). Public Expenditure and Economic Growth in the Gulf Cooperation Council Countries. Applied Economics, 34(9), 1187-1193.

Babatunde, M. (2011). A Bound Testing Analysis of Wagner's Law in Nigeria: 1970-2006. Applied Economics, 23(21), 2843-2850.

Barro, R. (1990). Government Spending in A Simple Model of Endogenous Growth. Journal of Political Economy, 98(S5), 103-125.

Barro, R. (1991). Economic Growth in A Cross Section of Countries. The Quarterly Journal of Economics, 106(2), 407-443.

Beblawi, H., \& Luciani, G. (1987). Introduction. In H. Beblawi, \& G. Luciani (Eds.), The Rentier State (p. 11). London: Croom Helm.

Bloom, D., Canning, D., \& Sevilla, J. (2004). The Effect of Health on Economic Growth: A Production Function Approach. World Development, 32(1), 1-13. http://dx.doi.org/10.1016/j.worlddev.2003.07.002

Burney, N. (2002). Wagner's Hypothesis: Evidence from Kuwait Using Cointegration Tests. Applied Economics, 34, $49-57$.

Central Bank of Kuwait. (2013). Public Expenditures by Ministries and Departments and Gross Domestic Product at Current Prices. Retrieved from http://www.cbk.gov.kw/cbkweb/servlet/cbkmain?Action=qbullet

Chen, B. (2006). Economic Growth with An Optimal Public Spending Composition. Oxford Economic Papers, 58(1), 123-136.

Devarajan, S., Swaroop, V., \& Zou, H. (1996). The Composition of Public Expenditure and Economic Growth. Journal of Monetary Economics, 37(2), 313-344.

Durevall, D., \& Henrikson, M. (2011). The Futile Quest for A Grand Explanation of Long-Run Government Expenditure. Journal of Public Economics, 95(7), 708-722.

Elliott, G., Rothenberg, T., \& Stock, J. (1996). Efficient Tests for An Autoregressive Unit Root. Econometrica, 64(4), 813-836.

Fasano, U., \& Wang, Q. (2002). Testing the relationship between government spending and revenue: Evidence from GCC countries. Washington, DC, USA: International Monetary Fund.

Glynn, J., Perera, N., \& Verma, R. (2007). Unit Root Tests and Structural Breaks: A Survey with Applications. Journal of Quantitative Methods for Economics and Business Administration, 3(1), 63-79. 
Gonzalo, J. (1994). Five alternative Methods of Estimating Long-Run Equlibrium Relationships. Journal of Econometrics, 60, 203-233.

Gordon, R. (2014). Macroeconomics (12th ed.). Boston, MA: Pearson Education.

Granger, C. (1969). Investigating Causal Relations by Econometric Models and Cross-Spectral Methods. Econometrica, 37(3), 424-438.

Granger, C. (1986). Developments in the Study of Cointegrated Economic Variables. Oxford Bulletin of Economics and Statistics, 48(3), 213-228.

IHS Global Inc. (2013). Eviews 8 User's Guide II. Eviews 8 Users Guide II, 482. Irvine, CA, USA: IHS Global Inc.

Johansen, S., \& Juselius, K. (1990). Maximum Likelihood Estimation and Inference on Cointegration-with Applications to the Demand for Money. Oxford Bulletin of Economics and Statistics, 52(2), 169-210.

MacKinnon, J. (1996). Numerical Distribution Functions for Unit Root and Cointegration Tests. Journal of Applied Econometrics, 11(6), 601-618.

Mankiw, N., Romer, D., \& Weil, D. (1992). A Contribution to the Empirics of Economic Growth. The Quarterly Journal of Economics, 107(2), 407-437.

Ministry of Finance of Kuwait (2005/06 - 2012/13). Government Final Accounts. Table (8) and Table (9). Retrieved from http://www.mof.gov.kw

Muhammad, F., Xu, T., \& Karim, R. (2015). Impact of Expenditure on Economic Growth in Pakistan. International Journal of Academic Research in Business and Social Sciences, 5(2), 231-236. http://dx.doi.org/10.6007/IJARBSS/v5-i2/1480

Munnell, A. (1992). Policy Watch: Infrastructure Investment and Economic Growth. The Journal of Economic Perspectives, 6(4), 189-198.

Özyavuz, A., \& Schmid, D. (2015). Persistence and Evolutions of the Rentier State Model in Gulf Countries. Note de l'Ifri, April issue.

Packey, D., \& Nasair, S. (2009). Kuwaiti Consumption in the Presence of Dramatic Economic Events: 1973-2003. Review of Middle East Economics and Finance, 5(2), 1-20. http://dx.doi.org/10.2202/1475-3693.1103

Perron, P. (1989). The Great Crash, the Oil Price Shock, and the Unit Root Hypothesis. Econometrica, 57(6), 1361-1401.

Public Authority for Civil Information. (2013). Population According to Sex and Nationality. Retrieved from http://www.paci.gov.kw

Riasi, A. (2015). Competitive Advantages of Shadow Banking Industry: An Analysis Using Porter Diamond Model. Business Management and Strategy, 6(2), 15-27. http://dx.doi.org/10.5296/bms.v6i2.8334

Riasi, A., \& Pourmiri, S. (2015). Effects of Online Marketing on Iranian Ecotourism Industry: Economic, Sociological, and Cultural Aspects. Management Science Letters, 5(10), 915-926. http://dx.doi.org/10.5267/j.msl.2015.8.005

Stauffer, T. (1987). Income Measurements in Arab States. In H. Beblawi, \& G. Luciani (Eds.), The Rentier State (p. 33). London: Croom Helm.

Tasseven, Ö. (2011). The Wagner's Law: Time series for Turkey, 1960-2006. Dogus University Journal, 12(2), 304-316.

Zivot, E., \& Andrews, D. (1992). Further Evidence on the Great Crash, the Oil-Price Shock, and the Unit-Root Hypothesis. Journal of Business and Economic Statistics, 10(3), 251-270.

\section{Copyrights}

Copyright for this article is retained by the author(s), with first publication rights granted to the journal.

This is an open-access article distributed under the terms and conditions of the Creative Commons Attribution license (http://creativecommons.org/licenses/by/3.0/) 